This was a mechanical failure, as it reduced the temperature only about 12 degrees, which was very little below the summer temperature.

I had the fortune to see in the spring of 1910 a patient with pellagra who had gone to Colorado for similar symptoms in 1909. She was then greatly relieved by the climate, according to her statement, and remained well; but the same influenees ol diet and hot weather induced another attack. She returned to the mountains of Colorado and was promptly relieved of all recognizable symptoms.

Since that time I have sent to Colorado four other patients, all of whon are symptomatically relieved. They have all gone to Denver and after spending a few days there to become accustomed to the altitude, three of them have gone higher up in the mountains. One of them was bed-ridden when she left here but was up in ten days and without recognizable symptoms of pellagra in two weeks.

I have sent two patients to Montengle, Tennessec, and they write that within one week they had improved wonderfully and almost all symptoms had disappeared.

These cases and others will be reported more in detail when the results obtained can be more definitely stated. This preliminary note is published now in order to suggest the treatment for the bencfit of the August and September crop of cases.

741 Carondelet Street.

\section{PARSIMONY IN NUTRITION}

\section{GEORGE M. NILES, M.D.}

Professol of l'hystology, Southern College of Pharmacy; Associate Professor of Fhysiology and Dieteties, Atlanta school of Medicine: Gastroenterologist to the 'Tubernacle Infirmary

- ATLANTA, as.

This title, adapted from a recent address of Sir James Crichton-Browne, represents a wide-spread dietetic movement which I view with some concern. l'revious to this century, throughout the history of the advancing civilizations of the earth, there has never been any concerted effort toward parsimony in nutrition; and, with the exception of certain ascetic orders, whose habits of self-denial were either religious or esthetic, the desires for food have been universally gratified, subject only to limitations of purse or environment. The doctrine that a strong body should be generously fed, and that a virile people should be hearty eater's, was of world-wide aceeptance. Furthermore, it was noted that the liberal consumers of the flesh proteins figured most largely in the arts of both peace and war, while the vegetarian nations either lagged behind, or were the servitors of their meateating masters.

In accordance with these historic and economic facts certain dietetic standards have been fixed, these standards being the aggi'egate result of statistical and experimental studies carried out by nany physiologists on numerous large groups of individuals under varying circumstances. These results were collected by Atwater, of this country, and Voit, of Munich, who found that an average individual under average conditions throve on a daily allowance of $118 \mathrm{gm}$. of protein food, $56 \mathrm{gm}$. of fat, and $500 \mathrm{gm}$. of carbohydrates, such as sugar and starch, this containing 3,055 large calories, or heat units. Under increased physical exercise this was raised to 3,370 calories. These findings were approxi- mated by a large number of independent observers, most of them, however, allowing a slightly higher daily protein ration.

'These standards having been settled with supposed immutability, all was serene until in the dietetic firmament there appeared a new galaxy. We were informed that the theories drawn from the dietetic exporience of untold millions of progressive and militant human beings, were altogether erroneous; and, like the man with the eight-day clock, who .wound it up every night for twenty-five years before he discovered his error, we have been partaking of double or treble the amount of "protein necessary for our well-being. We might say that after these eons the light has just broken in, opening up to us a new heaven and a new earth.

The advance guard of this new thought was $\mathrm{Mr}$. Horace Fletcher, a gentleman of intelligence and culture, who, finding himself obese, dyspeptic, and in declining health, accidentally discovered that by slow, deliberate eating he was much benefited. Being both observant and analytical, he reasoned out a theory that the whole process of bodily nutrition is materially affected by the preliminary treatment of food in the mouth; furthermore he became satisfied that by most thorough mastication and insalivation less food is required for adequate nutrition, while bodily conditions are improved. He sums up his philosophy as follows: "If you eat only when you have an earned appetite, masticate your food thoroughly, and take great care to eat only what your appetite approves, the rest will take care of itsell."

Like many other fads containing elements of truth this "chewing fad" attracted to it a circle of adherents, and, fortunately for $\mathrm{Mr}$. Fletcher, it canght the ear of some level-headed physiologists, among others the late Sir Michael Foster, of Cambridge, Fingland, and $\mathrm{Dr}$. Van Someren, of Venice, the latter of whom read a paper on "Fletcherism" before the Congress of PhysioJogists at Turin in 1901. 'This led to a series of experiments at Cambridge, which were later continued in America by Professor Chittenden, of Yule, the latter, however, losing sight of the chewing feature, cxecpt as it lessened the craving for food, and hinging his experiments on the momentous question: What is the proper daily protein ration best to meet the requirements of the average human body?

The investigations of Professor Chittenden, ${ }^{1}$ are in some respects epoch-making contributions to physiology. The experiments were on groups of professional men, army volunteers, athletes and animals, and proved to his entire satisfaction that $60 \mathrm{gm}$. of protein daily is sufficient for a man weighing 154 pounds, or practically one-half of the previously accepted standard. To quote his words :

These are perfectly trustworthy figures, with a reasonable margin of safety, and carrying perfect assurunce of really being more than suficient to meet the true wants of the body, adequate to supply all physiological demands for reserve protein, and able to cope with the erratic requirements of per. sonal idiosyncrasies.

The limits of this puper will not permit an anulysis of Professor Chittenden's experiments, showing where fallacies may exist, or where conclusions are lirawn on too meager evidence. He is a doughty antugonist, and one may well hesitate before breaking lances with either him or the formerly obese Mr. Fleteher. They have

1. Chittenden: Physlological Economy in Nutrition; and The Nutidion of Man. 
made out a strong case, but not an impregnable one, and I humbly suggest that we puuse and consider before revising our whole dietetic system, not simply, as expressed by the recent tarifi tinkers in Congress, "revising it downward," but absolutely eutting it down to half.

That a large percentage of the American people eat ton much is admitted; that a large percentage, especially the well-to-do, ingest a surplus almost from the cradle to the grave cannot be gainsaid. 'The great number of middle-aged and old people, who constantly throng the doctors' offices and health resorts, secking help for overtaxed eliminative organs, mournfully attest to past gastronomic excesses; but that the American people, as a nation, consume too much protein food, or that our national virility is handicapped by gluttony, cannot be conceded by any student of present-day history.

Leaving for a time the discussion of this subject in its larger aspects, a common illustration of parsimony in nutrition is the custom of some medical men of putting patients on dictaries withont duly considering the caloric values contained therein. It would be thought careless indeed should the physician, not know, in preseribing atropin or strychnin, how much in the aggregate was being taken daily; ret it is just as irrational to expect an invalid to gain strength on a diet furnishing insufficient calories, as to expect physiologic effects from inadequate doses of drugs.

I have several times seen persons unwittingly starved to a dangerous degree, and in one instance a case came under observation in which the patient, while being treated for an acute disease, was really starved beyond the power of recuperation before his true condition was recognized.

The appetite of healthy individuals or large groups of men will generally prove a reliable index to bodily needs, but in digestive disorders accompanied by malnutrition it is not enough for the physician to cut out offending articles of food; he should also see to it that sufficient calories are being furnished. Right here it is proper to sound a note of warning concerning the alcoholic proprictary foods on the market. As an auxiltary to other nourishment they have their place, and are not without value, but to give them in amounts large enough to meet ordinary caloric needs would result in continued alcoholic intoxication.

A few year's ago in New York (ity I saw a genuine attack of delirium tremens complicate a case of typhoid fever, in which for two weeks the patient had been generously "supposted" by a well-known and popular" propurietary food. In this connection $I$ wish to commend the thorough and impartial work of the Council on l'hamacy and Chemistry of the American Medical Association, whose very lucid reports have done much to dispel the glamour thrown about some of these alcoholic "supportives" and individually 1 desire to speed it in its meritorious labors.

The dry proprietary foods are equally unsutisfactory, because in adequate quantities they often disturb digestion more than the ordinary wholesome foods, while the caloric value claimed for them is unreasonable. Dr. David Ldsall, of Philadelphia, recently weighed a specimen of one of these dry toods, and reported that if all its weight were nutritive material (a liberal estimate), it was so light that it would take $\$ 1.25$ to $\$ 1.50$ to buy an amount equal in food value to a five-cent loaf of b) read.
Some of the most graphic examples of parsimony in nutrition are exhibited by infants (not the chubby ones with roly-poly little bodies extolling the virtues of various brands) whose eager digestive organs are vainly attempting to glean sustenance from some of the infant foods on the market.

Dr. John Howland, of New York, in a late paper on proprietary and predigested foods, showed by calculation that two of the most representative and widely used of these foods have little more than twice the nutritive value of whole milk, and that without the alcohol they contain the same nourishment as milk. The dose of these foods advised for a child of six months is a teaspoonful every four hours, which would give the infant the munificent equivalent of two ounces of milk daily! Dr. Howland further says:

Assuming that such a food could be ingested without grave gastric, intestinal or other disturbance in sufficient quantity to nourish the six-months-old infant, it would cost about a dollar a day, and would, moreover, require the child to take in twenty-four hours aleoliol equivalent to six ounces of brandy, enough to terminate his short life or lieep him in a continuous state of alcoholic coma.

Anotler greatly overrated class of foods leading to parsimony in nutrition are the meat-juices (not meat extracts), for which fabulous powers have been claimed. Well-expressed juice obtained from freshly chopped beef may contain a fair amount of actual nourishment in the form of coagulable proteins and meat bases, and is useful to tide over emergencies, or to satisfy the patient that he is being fed. It wotld take the stomach of a rhinoceros, however, to hold up under a continuous dict of meat juice for any length of time.

As to meat extracts, they are beyond parsimonythey are a delusion and a snare. 'To quote Dr. A. L. Benedict, of Buffalo.

A ment broth prepared at a temperature above $160^{\circ} \mathrm{F}$., the coagulation point of albumin, contains salts, extractives, which are mainly excrementitious, and a little gelutin, as well as some melted fat, although the last is often skimmed off to make the broth more pleasing and palatable. In so far as protein is comcerned, a meat tea made by boiling cannot be more nourishing than egg tea, that is to say the water in which eggs are poached, or in plain words, it contains no protein nourishment at all, and is, barring certuin qualitative and quantitative diffelences, of the same dietetic value as urine.

On such a regimen the patient may be fairly waterlogged with soup), and still get less than a hundred ealories daily. If strength holds up under such feeding, it is from the reserve protein and fat stored in the body, not from any decided nutritive virtue in the soup.

It is of course wise to provide for ceonomical use of the body fuel, just as engineers endeavor to get the most heat value from coal or wood burned in the furraces of their engines. It is also well to minimize the surplus ashes of combustion in the body, as the engineer keeps his grates cleared of clinkers. 'There is, though, a point beyond which economy ceases and parsimony begins, and there can certainly be no permanent healthy growth, nor can there be maintained a normal "moving equilibrium" in the bodies of individuals or nations unless there is a liberal intake of protein food, for, as Rub. ner declares, "A large protein allowance is the right of civilized man."

Sir James Crichton-Browne tersely puts it thus:

The health and welfare of individuals and of peoples must depend on right methods of living, and of all methods of liv 
ing the most momentous are those relating to the up-keep of the body by alimentation. It is food that supplies the material for that perpetual series of transformations in which life consists, and it must be adequate in quantity and suitable in quality, if these transformations are to proceed with that nicely balanced adjustment that is known as health.

Nutrition is therofore an important branch of preventive medicine.

It may be confidently asserted that no physiologic alchemy or mathematical legerdemain can ever hope to reduce materially the fixed demand for approximately $120 \mathrm{gm}$. of protein daily for every active individual of average weight. The late Sir William Roberts once said:

The generalized food customs of mankind are not to be viewed as random practices adopted to please the palate or gratify an idle or vicious appetite. These customs must be regarded as the outcome of profound instincts which correspond to certain wants of the human cconomy. They are the fruit of colossal experience aceumulated by countless millions of men through successive generations. They lave the same weight and significance as other kindred frets of natural history, and are fitted to yield to observation and study lessons of the highest scientific and practical value.

The foregoing thoughts are respectfully submitted to the sober students of both individual and collective problems of nutrition.

400 Candler Building.

\section{A CASE OF FRACTURE OF THE THYROID CARTILAGE WITH PROMPT RECOVIST}

\author{
A. C. MATTHEWS, M.D. \\ Assistant Physleinn, IIudson Rlver State Hospital \\ PouniLEersil, N. Y.
}

Fractures of the larynx are generally considered grave injuries. When one consider's the danger of suffocation from displacements of the fragments, or from edematous swelling, or from occlusion of the air-passages with blood-clots, one can unlerstand why a case of this kind should not be looked on lightly. Fisher pronounced every case serious. Gurlt in 1864 collected reports of 69 cases in which 47 patients died and only 21 recovered. Eastman ${ }^{1}$ quotes 1)urham, who collected reports of 30 cases of fracture of the thyroid cartilage, in ten of which the patients recovered, most of them after tracheotomy. During the past few years a few cases have been reported in which the symptoms were of" a mild type. The "American Practice of Surgery" states that tracheotomy is not usually necessary in the simple cases and those of vertical fracture of the thyroid, but is indicated in any fracture of the cricoid entilage. The case I observed was one without complications. Becausc it shows how exceedingly light the symptoms resulting from such a fracture may be I thought it worthy of publication.

An insane man (aged 49) was forcibly struck over the larynx by a fellow inmate. At the time no indications of injury were observer, and the patient went to the diningroom and ate his breakfast. Soon some hourseness developed. This soon becume more pronounced, and his throut appened somewhat filled un with mucus. There was a constant desire to swallow. An examination disclosed a complete vertical fracture of the thyroid in the median line. Crepitus was distinct, but there was no appurent displacemont. As there

1. Castman, I'. I3.: A case of fracture of the Thyroid Cartinge: libl, were no dyspnea, and no sign of suffocation, it was thought best to immobilize the fragments and await further developments. Immobilization was secured by padding on each side held in place by allesive strips. As swallowing culused slight movements of the frngments, the patieut was allowed no food for twenty-four hours. His voice continued hourse for four days; then there was a rapid improvement. On the -seventh duy the fixation strips were removed, and a perfect umion was found. On the ninth day the patient was up and about as usual.

Some surgeons believe that tracheotomy should be performed immediately.after such an injury in order to forestall suffocation. Eastman ${ }^{1}$ refers to Cohen, who says: "It is better that an unnecessary tracheotomy should occasionally be performed without detriment to the patient than that a number of cases should be allowed to terminate latally for the want of it." This is very true, but if the symptoms are of a mild type and the surgeon is in a position to render immediate service if the case demands it, one is justified, I believe, in delaying active procedure.

If the patient be allowed to swallow too early the fragments will be moved and mion interfered with. Weaver's patient" attempted swallowing at long inter. vals during the first twenty-four hours, but this moved the fragments. Weaver then resorted to nutritive enematas for three weeks. 'Tube-feeding through the mouth can be used to advantage in cases in which the throat is not too sensitive, so as to cause reflex movement of the larynx.

I take this opportunity of expressing my thanks to Dr. Cluns. W. Pilgrim, Supt. of the Hudson River State Hospital where this ease was observed, for the privilege of reporting it.

\section{A VOISSELLUM FORCEPS WITH DE'TACHABLE HANDIJES}

\section{A. IISRZFEL.D, M.D. NEW YORK}

Occasions frequently arise when curettage, or in fact any vaginal operative interference on the uterus, has to be done without sufficient assistance. In many cases for better orientation the grasping of the uterus has to be done through a bivalve speculum. It is very difficult,

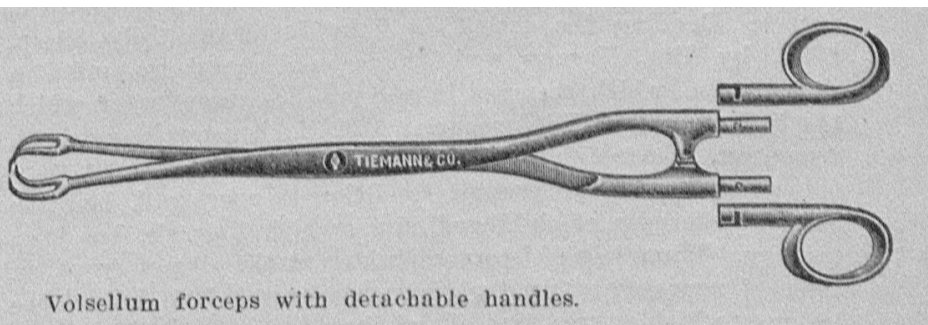

if not impossible to remove the bivalve speculum alter the uterus is grasped with the ardinary volsellum forceps on account of the width of the handles of the instrument. To facilitate the removal of the speculum, I devised a volsellum forceps with detuchable handles. The handles are easily applied and removed by means of a bayonet lock.

224 West Twenty-Fourth Street.

2. Wenvel, H. S.: Frncture of the Larynx, Habnemann Month. I'hlladelphia, 1001 xxxvi, 28:. 